\title{
Comparative analysis of the anthropological characteristics of children from Vojvodina (Serbia) and Belarus
}

\section{DOI: http://doi.org/10.26758/7.1.4}

Rada Rakić (1), Verica Božić-Krstić (1), Tatjana Pavlica (1), Branislava Belić (2), Lidia I. Tegako (3)

(1) The University of Novi Sad, Faculty of Sciences, Department of Biology and Ecology, Novi Sad, Serbia,

(2) The University of Novi Sad, Faculty of Agriculture, Novi Sad, Serbia

(3) Department of Anthropology and Ecology, Institute of History NAS of Belarus, Minsk, Belarus

Address correspondence to: Rada Rakić, The University of Novi Sad, Faculty of Sciences, Department of Biology and Ecology, Trg Dodsiteja Obradovića 2, 21000Novi Sad, Serbia, Tel: ++381 21485 2687; Fax: ++381 21450 620; E-mail: rada.rakic@ dbe.uns.ac.rs

\begin{abstract}
Objectives. Anthropological traits of a population offer an insight into nutritional and socioeconomic conditions of the region. The aim of the study was to compare anthropometric traits and body mass index in children from Vojvodina and Belarus.

Material and methods. The study is a part of a research project entitled "Variability of morphofunctional indicators in the population of Belarus and Vojvodina - The Republic of Serbia. The study was conducted in Vojvodina from 2001 to 2004 and in various areas of Belarus from 2005 to 2007. The total number of subjects in Vojvodina was 5874 (2879 boys and 2968 girls) and in Belarus 4406 (2268 boys and 2138 girls). All subjects were between 7 and 14 years of age. The survey included height, weight, chest circumference, and the body mass index $\left(\mathrm{BMI} \mathrm{kg} / \mathrm{m}^{2}\right)$ in relation to the age and sex.

Results. The results demonstrate that children from Vojvodina have significantly higher height, weight and chest circumference in relation to Belarus children, with an exception of the height values of 12-year-old girls. The average BMI is significantly higher in both boys and girls from Vojvodina, except for 11-year-old girls. The most noticeable differences in the means of weight, chest circumference, and BMI are recorded in 13-year-old subjects of both sexes. As for the height, the greatest variations are observed in 14-year-old boys and 10-year-old girls.

Conclusions. The study points to differences in morphological characteristics, however, the study is cross-sectional and implies that the establishment of individual criteria for assessing the growth is necessary for future.
\end{abstract}

Keywords: anthropometric traits; body mass index; children; Vojvodina; Belarus.

\section{Introduction}

Anthropometric traits provide insight into the growth, development, body constitution and health condition of a population. During their development, in the period of ontogenesis, both genetic and environmental factors have an influence on the traits. Environmental factors can speed up or slow down the growth and development of certain traits, especially at young age. 
As living conditions vary, both temporally and spatially, every region is characterized by a specific anthropological status. Anthropological status of a population offers an insight into the nutritional and socio-economic conditions of a region (Milici, 2015: 50). Some investigations emphasize the importance of assessing the dietary habits of the population, especially those of children and youth (Albu and Hodorca, 2014; Milici, 2016), because at this age healthy lifestyle knowledge has great chances to be established as an ally for the entire life (Zugravu, Rada and Nitu, 2009). Bad-living habits contribute to increasing the percentage of overweight children and require that parents and children should be better informed about the effects of an unhealthy diet on children's development (Baciu, 2011; Milici, 2016).

The study of variability in morpho-functional characteristics of the populations of Vojvodina (Serbia) and Belarus is a part of a mutual project with colleagues from Belarus. Vojvodina and Belarus have been characterized by different processes of economic development and changes in living conditions during the last few decades. The growth and development of basic anthropometric traits in children and adolescents have been studied by a number of authors in Serbia (Gavrilović, 1972; Gavrilović et al. 1987; Božić-Krstić, 1986; Božić-Krstić, Pavlica and Rakić, 2004; Pavlović, 1999; Rakić, Božić-Krstić and Pavlica, 2004; Rakić, Božić-Krstić and Pavlica, 2011) and Belarus (Тегако и сар. 2008a; Tegako, Marfina and Hurbo, 2008b; Tegako and Marfina, 2008c; Marfina, 2015).

As the variability in children and adolescents' growth reflects differences in the quality of their surroundings, anthropological results processed comparatively for different populations of the same age category can explain the influence of certain factors on the dynamics of growth and development in children. Comparative regional studies on the physical growth of children and adolescents can detect variability in the period of growth.

Regarding everything stated above, the aim of the present study was to compare anthropometric traits and body mass index in children from Vojvodina and Belarus.

\section{Material and methods}

A cross-sectional anthropometric study was conducted in Vojvodina from 2001 to 2004 and in various areas of Belarus from 2005 to 2007. The total number of subjects in Vojvodina was 5874 ( 2879 boys and 2968 girls) and in Belarus 4406 (2268 boys and 2138 girls). All subjects were between 7 and 14 years of age and for the purpose of this study their decimal age (based on the date of investigation and birth date) was calculated.

The anthropometric study was performed in compliance with the International Biological Programme and included three traits: stature/height $(\mathrm{cm})$, weight $(\mathrm{kg})$ and mid-chest circumference $(\mathrm{cm})$. The stature measurements were performed using the Martin anthropometer, to the nearest 0.1 $\mathrm{cm}$, the weight was measured on an electronic digital scale with an accuracy of up to $0.1 \mathrm{~kg}$ and the mid-chest circumference measures were obtained using the steel tape to the nearest $0.1 \mathrm{~cm}$. The body mass index $(\mathrm{BMI})$ was derived from the weight $(\mathrm{kg})$ and height $\left(\mathrm{m}^{2}\right)$ ratio.

Statistical data processing was completed by IBM SPSS 20 Statistics and the results are presented as means and standard deviation (SD) values. The Student t-test was applied for determining the differences in the traits and BMI values recorded in two investigations and the BMI percentiles $\left(3^{\text {rd }}, 10^{\text {th }}, 25^{\text {th }}, 50^{\text {th }}, 75^{\text {th }}, 90^{\text {th }}\right.$ and $\left.97^{\text {th }}\right)$ were obtained. In all analyses, the statistical significance was set at $\mathrm{p}<0.05$. 


\section{Results}

Table 1 shows basic statistical parameters of the stature in relation to the gender and age of children from Vojvodina and Belarus.

\begin{tabular}{|l|c|c|c|c|c|c|c|c|c|c|}
\hline Table 1. The stature (cm) of children from Vojvodina and Belarus \\
\hline & \multicolumn{3}{|c|}{ Vojvodina } & & \multicolumn{3}{|c|}{ Belarus } & & & \\
\hline & $\mathrm{N}$ & Mean & SD & & $\mathrm{N}$ & Mean & SD & t-test & $\mathrm{p}$ & Difference \\
\hline Boys & & & & & & & & & & \\
\hline 7 & 313 & 126.17 & 6.11 & & 359 & 123.95 & 5.85 & 4.785 & $* *$ & 2.22 \\
\hline 8 & 380 & 130.94 & 6.68 & & 327 & 129.48 & 5.85 & 3.091 & $* *$ & 1.46 \\
\hline 9 & 366 & 136.18 & 6.58 & & 192 & 134.00 & 6.91 & 3.601 & $* *$ & 2.18 \\
\hline 10 & 349 & 140.33 & 6.94 & & 218 & 138.85 & 5.86 & 2.716 & $* *$ & 1.48 \\
\hline 11 & 369 & 147.31 & 7.23 & & 125 & 145.07 & 7.35 & 2.963 & $* *$ & 2.24 \\
\hline 12 & 355 & 153.04 & 8.10 & & 290 & 150.09 & 7.23 & 4.887 & $* *$ & 2.95 \\
\hline 13 & 359 & 160.53 & 8.80 & & 471 & 156.77 & 8.71 & 6.121 & $* *$ & 3.76 \\
\hline 14 & 388 & 167.20 & 8.72 & & 286 & 163.09 & 8.94 & 5.968 & $* *$ & 4.11 \\
\hline Girls & & & & & & & & & & \\
\hline 7 & 320 & 124.82 & 6.01 & & 329 & 123.31 & 5.85 & 3.244 & $* *$ & 1.51 \\
\hline 8 & 395 & 129.81 & 5.89 & & 190 & 128.53 & 6.04 & 2.420 & $* *$ & 1.28 \\
\hline 9 & 343 & 135.41 & 6.64 & & 202 & 133.36 & 6.21 & 3.620 & $* *$ & 2.05 \\
\hline 10 & 362 & 141.81 & 6.92 & & 199 & 139.13 & 6.76 & 4.447 & $* *$ & 2.68 \\
\hline 11 & 387 & 147.74 & 7.60 & & 130 & 145.67 & 7.49 & 2.710 & $* *$ & 2.07 \\
\hline 12 & 387 & 153.74 & 7.52 & & 305 & 152.67 & 7.18 & 1.905 & ns & 1.07 \\
\hline 13 & 402 & 159.68 & 6.34 & & 498 & 157.44 & 6.95 & 5.045 & $* *$ & 2.24 \\
\hline 14 & 372 & 162.49 & 6.33 & & 285 & 160.92 & 6.29 & 3.172 & $* *$ & 1.57 \\
\hline
\end{tabular}

ns- no statistical difference; $* \mathrm{p}<0.05 ; * * \mathrm{p}<0.01$

It can be observed (Table 1) that stature generally increases with age in both boys and girls. Greater variability is detected in 11-year-old boys and girls aged 11 and 12 years, in both Vojvodina and Belarus subjects. Except for 12-year-old girls, the children from Vojvodina show significantly higher stature values than Belarussian boys and girls. In boys, the difference in stature increases with age, starting at the age of 10 , and reaches the maximum at the age of $14(4.11 \mathrm{~cm})$. In girls, the greatest difference is observable at the age of $10(2.68 \mathrm{~cm})$.

Table 2 shows in parallel the weight mean values of boys and girls coming from Vojvodina and Belarus.

Table 2. The weight means (kg) in children from Vojvodina and Belarus

\begin{tabular}{|l|c|c|c|c|c|c|c|c|c|c|}
\hline & \multicolumn{3}{|c|}{ Vojvodina } & \multicolumn{3}{c|}{ Belarus } & \multicolumn{3}{c|}{} & \\
\hline & $\mathrm{N}$ & Mean & SD & & $\mathrm{N}$ & Mean & SD & t-test & $\mathrm{p}$ & Difference \\
\hline Boys & & & & & & & & & & \\
\hline 7 & 313 & 27.92 & 5.69 & & 359 & 24.93 & 3.98 & 7.775 & $* *$ & 2.99 \\
\hline 8 & 380 & 30.31 & 6.72 & & 327 & 27.83 & 5.03 & 5.598 & $* *$ & 2.48 \\
\hline
\end{tabular}




\begin{tabular}{|l|c|c|c|c|c|c|c|c|c|c|}
\hline 9 & 366 & 33.70 & 8.02 & & 191 & 30.79 & 5.42 & 5.072 & $* *$ & 2.91 \\
\hline 10 & 349 & 36.44 & 8.25 & & 218 & 33.99 & 7.01 & 3.776 & $* *$ & 2.45 \\
\hline 11 & 369 & 42.02 & 11.56 & & 125 & 38.66 & 8.66 & 3.424 & $* *$ & 3.36 \\
\hline 12 & 355 & 46.69 & 11.01 & & 291 & 41.31 & 8.09 & 7.152 & $* *$ & 5.38 \\
\hline 13 & 359 & 52.39 & 11.43 & & 470 & 45.55 & 9.49 & 9.184 & $* *$ & 6.84 \\
\hline 14 & 388 & 58.43 & 11.92 & & 284 & 51.85 & 11.44 & 7.235 & $* *$ & 6.58 \\
\hline Girls & & & & & & & & & & \\
\hline 7 & 320 & 26.57 & 5.04 & & 328 & 24.42 & 4.31 & 5.840 & $* *$ & 2.15 \\
\hline 8 & 395 & 29.14 & 5.56 & & 190 & 26.53 & 4.60 & 5.997 & $* *$ & 2.61 \\
\hline 9 & 343 & 32.97 & 7.20 & & 203 & 29.47 & 6.55 & 5.814 & $* *$ & 3.50 \\
\hline 10 & 362 & 36.82 & 8.41 & & 199 & 32.65 & 6.71 & 6.421 & $* *$ & 4.17 \\
\hline 11 & 387 & 40.62 & 9.60 & & 131 & 38.10 & 10.04 & 2.515 & $*$ & 2.52 \\
\hline 12 & 387 & 46.28 & 10.45 & & 305 & 42.16 & 9.01 & 5.568 & $* *$ & 4.12 \\
\hline 13 & 402 & 52.39 & 10.94 & & 498 & 46.64 & 9.62 & 8.267 & $* *$ & 5.75 \\
\hline 14 & 372 & 55.69 & 10.13 & & 285 & 50.67 & 8.98 & 6.716 & $* *$ & 5.02 \\
\hline
\end{tabular}

$* \mathrm{p}<0.05 ; * * \mathrm{p}<0.01$

The analysis of the results presented in the table above points to an increase in weight in boys and girls coming from both Vojvodina and Belarus. A noticeable variability in weight values is particularly observed in children older than 11 years, in both Vojvodina and Belarus. Children from Vojvodina show significantly higher weight values in relation to the children of the same age living in Belarus. The greatest difference is recorded in children aged 13 and 14.

The basic statistical parameters of mid-chest circumference in relation to the gender, age and area of residence are presented in Table 3.

Table 3. The means of mid chest circumference $(\mathrm{cm})$ of children from Vojvodina and Belarus

\begin{tabular}{|l|c|c|c|c|c|c|c|c|c|c|}
\hline & \multicolumn{3}{|c|}{ Vojvodina } & & \multicolumn{3}{c|}{ Belarus } & & \\
\hline & $\mathrm{N}$ & Mean & $\mathrm{SD}$ & & $\mathrm{N}$ & Mean & SD & t-test & $\mathrm{p}$ & Difference \\
\hline Boys & & & & & & & & & & \\
\hline 7 & 313 & 63.74 & 5.32 & & 346 & 60.42 & 3.44 & 9.391 & $* *$ & 3.32 \\
\hline 8 & 380 & 65.53 & 5.66 & & 290 & 61.65 & 3.98 & 10.420 & $* *$ & 3.88 \\
\hline 9 & 366 & 68.11 & 6.89 & & 157 & 64.39 & 4.54 & 7.286 & $* *$ & 3.72 \\
\hline 10 & 349 & 70.11 & 6.89 & & 184 & 67.14 & 6.20 & 5.066 & $* *$ & 2.97 \\
\hline 11 & 369 & 73.80 & 8.46 & & 119 & 70.36 & 7.23 & 4.325 & $* *$ & 3.44 \\
\hline 12 & 355 & 76.40 & 7.94 & & 272 & 72.28 & 6.54 & 7.127 & $* *$ & 4.12 \\
\hline 13 & 359 & 79.66 & 8.15 & & 452 & 73.73 & 6.44 & 11.266 & $* *$ & 5.93 \\
\hline 14 & 388 & 83.52 & 7.74 & & 272 & 78.46 & 8.36 & 7.890 & $* *$ & 5.06 \\
\hline Girls & & & & & & & & & & \\
\hline 7 & 320 & 62.33 & 5.09 & & 311 & 59.69 & 4.06 & 7.209 & $* *$ & 2.64 \\
\hline 8 & 395 & 63.98 & 5.36 & & 153 & 61.22 & 4.91 & 5.748 & $* *$ & 2.76 \\
\hline 9 & 343 & 67.13 & 6.56 & & 168 & 62.78 & 5.18 & 8.146 & $* *$ & 4.35 \\
\hline 10 & 362 & 69.87 & 6.97 & & 179 & 65.77 & 6.23 & 6.926 & $* *$ & 4.10 \\
\hline
\end{tabular}




\begin{tabular}{|l|l|l|l|l|l|l|l|l|l|l|}
\hline 11 & 387 & 72.59 & 7.41 & & 120 & 70.44 & 8.14 & 2.575 & $*$ & 2.15 \\
\hline 12 & 387 & 76.71 & 7.75 & & 279 & 74.58 & 8.34 & 3.356 & $* *$ & 2.13 \\
\hline 13 & 402 & 81.01 & 7.42 & & 465 & 76.22 & 7.05 & 9.702 & $* *$ & 4.79 \\
\hline 14 & 372 & 83.34 & 5.80 & & 259 & 81.65 & 6.45 & 3.366 & $* *$ & 1.69 \\
\hline
\end{tabular}

$* \mathrm{p}<0.05 ; * * \mathrm{p}<0.01$

The results in Table 3 show that the mid-chest circumference values increase with age in children from both countries. A greater variability is observed for the ages of 11-14 in boys and for the ages of 11-13 in girls, in both investigations. Children from Vojvodina show significantly higher values of mid-chest circumference, with the greatest difference appearing in 13-year-old boys and girls $(5.93 \mathrm{~cm}$ and $4.79 \mathrm{~cm}$, respectively).

The means of BMI are given in Table 4.

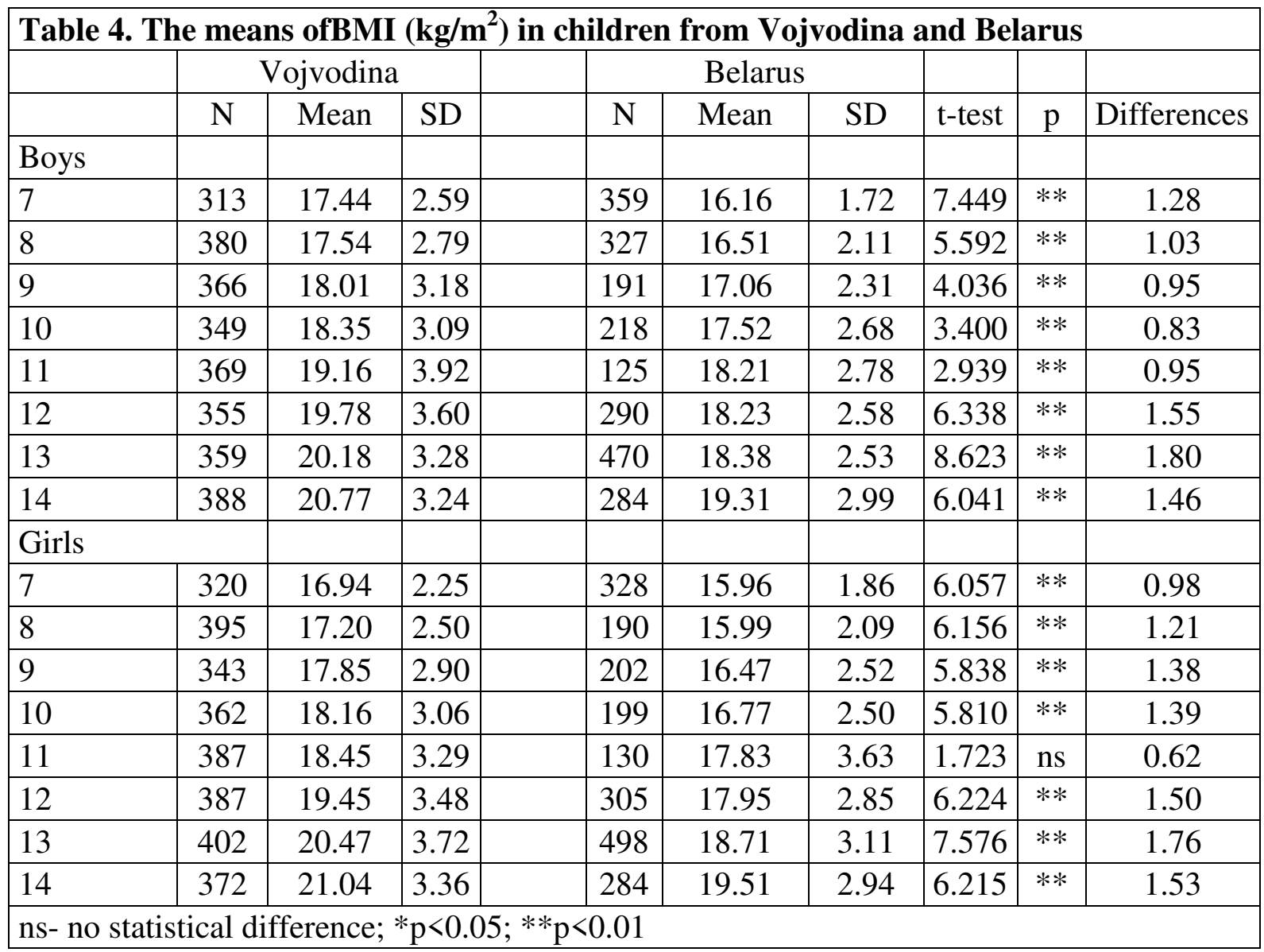

As it is seen in Table 4, boys and girls from Vojvodina have significantly higher BMI values in all the age groups, except for the 11-year-old girls (Table 4).

The percentile values of BMI obtained for boys and girls coming from the two countries are presented in Table 5. 


\begin{tabular}{|c|c|c|c|c|c|c|c|c|c|c|c|c|c|c|}
\hline & \multicolumn{7}{|c|}{ Vojvodina } & \multicolumn{7}{|c|}{ Belarus } \\
\hline & 3 & 10 & 25 & 50 & 75 & 90 & 97 & 3 & 10 & 25 & 50 & 75 & 90 & 97 \\
\hline \multicolumn{15}{|c|}{ Boys } \\
\hline 7 & 14.3 & 14.8 & 15.7 & 17.0 & 18.6 & 21.0 & 24.0 & 13.8 & 14.4 & 15.0 & 15.8 & 17.1 & 18.2 & 20.5 \\
\hline 8 & 14.2 & 14.8 & 15.8 & 16.8 & 18.7 & 21.1 & 24.3 & 13.6 & 14.2 & 15.2 & 16.2 & 17.4 & 19.7 & 21.6 \\
\hline 9 & 14.1 & 14.9 & 15.8 & 17.3 & 19.2 & 22.6 & 26.5 & 14.0 & 14.8 & 15.7 & 16.6 & 18.0 & 20 & 21.7 \\
\hline 10 & 14.7 & 15.3 & 16.0 & 17.5 & 20.1 & 22.9 & 24.9 & 14.6 & 15.1 & 15.8 & 16.8 & 18.5 & 20.8 & 24.0 \\
\hline 11 & 14.9 & 15.3 & 16.5 & 18.2 & 20.9 & 24.2 & 28.2 & 14.8 & 15.6 & 16.2 & 17.6 & 19.2 & 22.4 & 24.8 \\
\hline 12 & 15.1 & 15.9 & 17.2 & 18.9 & 21.8 & 25.0 & 28.2 & 14.9 & 15.6 & 16.4 & 17.8 & 19.5 & 21.6 & 24.1 \\
\hline 13 & 15.4 & 16.8 & 17.9 & 19.4 & 22.0 & 24.4 & 27.9 & 14.9 & 15.8 & 16.7 & 18.0 & 19.4 & 21.7 & 23.9 \\
\hline 14 & 16.1 & 17.2 & 18.6 & 20.2 & 22.4 & 25.2 & 28.8 & 15.4 & 16.4 & 17.4 & 18.7 & 20.5 & 23.1 & 27.3 \\
\hline \multicolumn{15}{|c|}{ Girls } \\
\hline 7 & 13.6 & 14.5 & 15.3 & 16.6 & 17.9 & 20.3 & 22.4 & 13.4 & 14.2 & 14.7 & 15.6 & 16.9 & 18.4 & 20.6 \\
\hline 8 & 13.8 & 14.6 & 15.4 & 16.7 & 18.3 & 20.6 & 23.6 & 13.2 & 13.8 & 14.6 & 15.7 & 16.8 & 18.5 & 21.5 \\
\hline 9 & 14.0 & 14.9 & 15.7 & 17.2 & 19.3 & 22.0 & 25.1 & 13.4 & 14 & 14.8 & 15.9 & 17.7 & 19.4 & 22.2 \\
\hline 10 & 14.2 & 15.0 & 15.9 & 17.6 & 19.6 & 22.5 & 25.7 & 13.6 & 14.3 & 15.1 & 16.1 & 17.8 & 19.9 & 23.2 \\
\hline 11 & 14.5 & 15.2 & 16.2 & 17.7 & 19.7 & 23.4 & 26.2 & 14.3 & 14.8 & 15.6 & 17.0 & 18.8 & 21.2 & 24.4 \\
\hline 12 & 14.9 & 16.0 & 17.0 & 18.5 & 21.1 & 24.3 & 27.9 & 14.2 & 15.0 & 16.1 & 17.3 & 19.2 & 21.1 & 24.6 \\
\hline 13 & 15.4 & 16.4 & 17.9 & 19.7 & 22.3 & 25.8 & 29.2 & 14.5 & 15.4 & 16.6 & 18.3 & 20.2 & 22.8 & 25.7 \\
\hline 14 & 16.3 & 17.5 & 18.7 & 20.6 & 22.8 & 24.8 & 29.3 & 15.2 & 16.3 & 17.6 & 19.1 & 21.2 & 23.2 & 25.6 \\
\hline
\end{tabular}

According to the distribution of BMI percentiles in relation to the gender and age, higher values are observed in subjects of all ages coming from Vojvodina (Table 5).

The value of $50^{\text {th }}$ percentile in 14-year-old boys from Vojvodina equals $20.2 \mathrm{~kg} / \mathrm{m}^{2}$ and in Belarussian boys it is $18.7 \mathrm{~kg} / \mathrm{m}^{2}$, making thus the difference of $1.5 \mathrm{~kg} / \mathrm{m}^{2}$. In girls, the difference is $1.4 \mathrm{~kg} / \mathrm{m}^{2}$ (20.6 and $19.1 \mathrm{~kg} / \mathrm{m}^{2}$ in Vojvodina and Belarus, respectively).

\section{Discussion}

The paper presents a comparative analysis of some anthropometric traits of children from Vojvodina and Belarus, focusing on the major anthropometric traits for assessing the body size of an individual or a population. The results suggest that the children from Vojvodina are characterized by higher values of stature (except for the 12-year-old girls), weight, mid-chest circumference and body mass index (with the exception of the 11-year-old girls) in comparison with Belarussian children. The differences can be explained by different genetic and environmental factors, including socioeconomic conditions, lifestyle, the degree of physical activity and nutritional habits.

Comparing the obtained results of stature, weight and body mass index with relevant literature data, the children in this study show greater values of the three traits in relation to children from Bahrain (Gharib and Rasheed, 2009) and from Arak-Central Iran (Bayat et al. 2012), but lower than the values reported for children from Cyprus (Savvas et al. 2001). In comparison with children from Bucharest (Radu et al. 2006-2007), Belarussian boys and girls have lower means of stature, weight, and body mass index. 
In relation to the data obtained in Western Romania (Emandi et al. 2012), Belarussian boys and girls are characterized by lower stature and weight, and the same is noticed for certain ages groups among children from Vojvodina. The results of this study also suggest that boys and girls from Vojvodina and Belarus show greater stature and weight in comparison with Polish (Niewiadomska et al. 2011) and Turkish (Oner et al. 2004) children, with the exception of the12year-old Belarussian girls in the latter case.

As a result of entering the period of puberty, the girls analyzed in this study appear to be taller than boys at the ages of 10,11 and 12, this phenomenon being observed in both countries. The greatest annual increase in boys' stature is noticed at the age of 13, in both Vojvodina and Belarus, which is in line with the data found in the literature (Božić-Krstić, 1986; Emandi et al. 2012). The absolute annual increase of weight and mid-chest circumference is greatest among 14-year-old boys from both Vojvodina and Belarus, while in girls, this is observed at earlier ages.

The data referring to BMI indicates that the values recorded for boys aged 7-9 and girls aged 7-10 in this study are smaller than those reported for children in Greece (Tzotzas et al. 2011). In addition, the $50^{\text {th }}$ percentile of the oldest boys in this study (14 years of age) appears to be lower than in the case of boys from Cyprus (Savvas et al. 2001), Bucharest (Radu et al. 2006-2007) and Western Romania (Emandi et al. 2012).

\section{Conclusion}

The boys from Vojvodina, in all the age groups, have higher values for the observed parameters compared to their peers in Belarus. For girls, the same can be generally concluded, except for stature of 12-year-old girls and likewise for weight, mid-chest circumference and BMI of 11-year-old girls.

These differences between subjects from Vojvodina and Belarus can be explained by genetic factors, but also various exogenous factors that influence the growth and development of children in the two observed populations.

\section{Bibliography}

1. Albu, A., and Hodorca, R., 2014. Assessment and food correlation between body weight in a group of students from sports high school Iassy. Sp Soc Int J Ph Ed Sp, 14(1), pp. 15-8

2. Baciu, A., 2011. Anthropological-medical aspects of feeding behavior of children in modern society. RGMHR, 2(1), pp. 79-99.

3. Bayat, P.D., Khazaei, M., Ghorbani, R., Ayubian, M., Sohouli, P., and Ghanbari, A. 2012. Growth pattern in 7-12 years old Arak children (central Iran) in comparison with other ethnic subgroups of Iran. IJAE, 117(1), pp. 1-7.

4. Božić-Krstić, V., 1986. Telesni rast i razvoj učenika od 7 do 18 godina. Zbornik matice srpske za prirodne nauke, 71, pp. 131-44.

5. Božić-Krstić, V., Pavlica, T., and Rakić, R., 2004. Body height and weight of children in Novi Sad. Ann Hum Biol, 31(3), pp. 356-63.

6. Emandi, C. A., Puiu, M., Gafencu, M., and Pienar, C., 2012. Growth references for school aged children in Western Romania. Acta Endocrinologica (Buc), VIII (1), pp.133-52.

7. Gavrilović, Ž., 1972. Prilog proučavanju visine i težine tela dece školskog uzrasta iz centra I sa periferije u Novom Sadu. Zbornik za prirodne nauke, Matica srpska, 43, pp. 99-107. 
8. Gavrilović, Ž., Petrov, I., Nikolov, M., i Selaković, D., 1987. Neke karakteristike telesnog razvoja školske dece u Novom Sadu i Plovdivu. Zbornik radova PMF, Novi Sad, Ser. Biol. 17, pp. 5-13.

9. Gharib, N., and Rasheed, P., 2009. Anthropometry and body composition of school children in Bahrain. Ann Saudi Med, 29(4), pp. 258-69.

10. Marfina, O., 2015. Comparative analysis of physical development of children, teen-agers and youth from different countries at the end of the 1990s-the beginning of the 2000s. Papers on Anthropology XXIV/1, pp. 120-28.

11. Milici, N., 2015. Sindromul metabolic şi obezitatea. Perspective antropologice (Metabolic syndrome and obesity. Anthropological perspectives). Bucureşti: Editura Academiei Române.

12. Milici, N., 2016. Comportements alimentaires désordonnés. In: Svetoslav Handjiev (Ed.) Mondialisation des comportaments alimentaires et facteurs de risques pour l'obésité et le diabète. Sofia: Simel Press Edt.

13. Niewiadomska, E., Czech, E., Niewiadomski, A., Kasznia-Kocot, J., and Skrzypek, M., 2011. An analysis of characteristics of children and adolescents physical growth in the context of social and economical situation of families inhabiting the city of Bytom. Studies in Logical, Grammar and Rhetoric, 25 (38), pp. 59-72.

14. Oner, N., Vatansever, U., Sari, A., Ekuklu, G., Guzel, A., Karasalihoglu, S., Boris, N.W., 2004. Prevalence of underweight, overweighr and obesity in Turkish adolescents. Swiss Med Wikly, 134, pp. 529-33.

15. Pavlović, M., 1999. Nutritional status of children in North Bačka Region. Public Health Institute Subotica, Yugoslavia, pp. 272.

16. Radu, E., Ciotaru L. O., Sandru, C., and Macovei, A., 2006-2007. Body mass variability in children aged 11-18. Ann. Roum. Anthropol, 43-44, pp. 159-78.

17. Rakić, R., Božić-Krstić, V., and Pavlica, T., 2004. Indicators of growth and development of primary school children in Sombor. Glasnik antropološkog društva Jugoslavije, Journa of the anthropologycal society of Yugoslavia, 39, pp. 115-22.

18. Rakic, R., Bozic-Krstic, V., Pavlica, T., 2011. Relationship between overweight, obesity and socioeconomic factors of adolescents in Vojvodina, Serbia. HOMO-Journal of Comparative Human Biology, 62, pp. 307-13.

19. Savvas, S. C., Kourides, Y., Tornaritis, M., Epiphaniou-Savva, M., Tafouna, P., and Kafatos, A., 2001. Reference growth curves for Cypriot children 6 to 17 years of age. Obes Res. 9(12), pp. 754-62.

20. Тегако, Л.И., Саливон, И. И., Марфина, О. В., Гурбо, Т. Л., 2008. Таблиць1 оценки физического развития детей, подростков и молодежи Республики Беларусь. ИООО Право и экономика, Минск, пп, рр. 3-23.

21. Tegako, L.V., Marfina O. V., and Hurbo, T. L., 2008b. Monitoring of physical development of children and teenagers in Republic of Belarus. Актуальньие ВопросьI Антропологии, 2, pp. 26-36.

22. Tegako, L., and Marfina, O., 2008c. Dynamic observation of physical development indices of schoolchildren in the Republic of Belarus. Papers on Anthropology, 17, pp. 272-81.

23. Tzotzas, T., Kapantais, E., Tziomalos, K., Ioannidis, I., Mortoglou, A., Bakatselos, S., Kaklamanou, M., Lanaras, L., and Kaklamanou, D., 2011. Prevalence of overweight and abdominal obesity in Greek children 6-12 years old: Results from the National Epidemiological Survey. Hippokratia, 15 (1), pp. 48-53.

24. Zugravu, C.A., Rada, C., and Nitu, G., 2009. Nutritional knowledge, healthy behavior and selfevaluation of body weight in a sample of Romanian adolescents. Eur J Epidemiol, 24(1), pp. 90. 